\title{
Tietoja Helsingin suurista ja keski- suurista perheistä sekä niiden oloista vuonna 1943
}

\author{
TILASTOLLINEN SELVITYS
}

Laatinut Armas Nieminen.

$$
\text { I. JOHDANTO. }
$$

1. Selvityksen toimeenpano.

Väestöliitto tarvitsee toiminnassaan suurten perheiden hyväksi mahdollisimman täydellisiä ja tarkkoja tietoja sellaisista perheistä ja niiden oloista. Mutta näitä asioita valaisevia selvityksiä ei juuri ole olemassa. Väestöpoliittisten näkökohtien mukaan järjestetyt suurisuuntaiset tilastolliset tutkimukset taas ovat siksi työläitä ja siksi suuria kustannuksia vaativia, ettei liitto toimintansa alkuaikoina ole saattanut niitä ryhtyä suorittamaan. Sen vuoksi on pyritty käyttämään vähäisiäkin mahdollisuuksia tietojen saamiseksi monilapsisten perheiden oloista.

Tässä mielessä Väestöliiton hallitus päätti kansanhuoltoministeriön suostumuksella ja Helsingin kansanhuoltolautakunnan myötävaikutuksella käyttäen hyväksi maaliskuussa 1943 suoritettavaa elintarvikekorttien jakelua toimeenpanna selvityksen niidén perheiden oloista, joilla oli oikeus saada suurempaan viljatuotteiden jakelumäärään oikeuttavat ostokortit sekä lisärasvakortit. Tutkittavat perheet olivat siis sellaisia, joihin niiden yhteydessä 
asuvina perheenjäseninä kuului vähintään neljä vuonna 1925 tai sen jälkeen syntynyttä lasta. Perheen yhteydessä asuviksi perheenjäseniksi luettiin tällöin perheen päähenkilön tai hänen aviopuolisonsa mainittuna aikana syntyneet lapset ja ottolapset, jotka pysyväisesti asuivat ja säännöllisesti nauttivat pääasiallisen päivittäisen ravintonsa samassa perheessä.

Tutkimus toimeenpantiin nimenomaan ostokorttijakelun yhteydessä, koska tässä suuret ja keskisuuret perheet olivat erikoisasemassa. Näin ollen saatettiin käyttäen hyväksi elintarvikekorttien jakelun edellyttämää organisaatiota tutkimusaineiston keräyksen aiheuttamatta mitään lisäkustannuksia hankkia tietoja lisäostokortteihin oikeutetuista perheistä ja niiden oloista. Selvitys päätettiin kuitenkin ainakin aluksi rajoittaa koskemaan vain Helsingin kaupungissa asuvia perheitä.

Tutkimuksen järjestelyä sekä kyselylomakkeen sisältöä ja muotoa koskeviin neuvotteluihin ottivat osaa Väestöliiton puheenjohtaja, fil.toht. V. J. Sukselainen ja toiminnanjohtaja, hovioik. ausk. Heikki von Hertzen, fil.maist. Gunnar Fougstedt, agronomi Erkki J. Kinnunen, fil.maist. Iisakki Laati, maat. ja metsät. kand. Artturi A. Lehtinen, kanslianeuvos, fil. maist. G. Modeen, fil.maist. Elli Saurio sekä tutkimuksen suorittaja, fil.maist. Armas Nieminen.

Tutkimusaineiston keräämiseksi jaettiin yksityiskohtaiset painetut kyselylomakkeet ostokorttien ohella lisäkortteihin oikeutetuille perheille täytettäviksi ja palautettaviksi talojen isännöitsijäin välityksellä kansanhuoltolautakunnalle, joka ne toimitti edelleen Väestöliitolle.

Palautetut lomakkeet oli yleensä täytetty tunnollisesti. Puutteellisuuksiakin kuitenkin ilmeni, mutta ne saatiin miltei poikkeuksetta korjatuiksi puhelimitse ja henkilökohtaisilla käynneillä suoritetuilla täydennystiedusteluilla. Useimmin esiintyviä vajavaisuuksia olivat puutteelliset tiedot kuukausituloista, vanhempien ammatista ja koulusivistyksestä, vuokran suuruudesta sekä asunnon pinta-alasta.

Tutkimusaineisto tuli lisätiedustelujen jälkeen käsittämään kaikkiaan 575 täytettyä kyselylomaketta. Aineiston alkukäyttely suoritettiin Väestöliiton toimistossa. 


\section{Tutkimusaineistosta johtuvat rajoitukset.}

Selvityksen tulosten merkityksen arvostelemiseksi olisi tarpeen tietää, kuinka suuren osan 575 tutkittua perhettä muodosti kaikista nuistä helsinkiläisistä perheistä, jotka olivat oikeutettuja lisäostokorttien saantiin ja jotka siis kuuluivat tutkimuksen kohteena olevaan perheiden ryhmään. Tätä tietoa ei kuitenkaan ole mahdollista tarkkaan ilmoittaa, koska Helsingin kansanhuoltolautakunnassakaan ei tästä asiasta ole tehty minkäänlaista tilastoa. Näin ollen ei ole selvyyttä siitä, kuinka monta perhettä niistä, jotka tämän selvityksen toimittamisaikana olisivat ominaisuuksiensa puolesta olleet tutkimuksenalaisia, tosiasiallisesti on jäänyt selvityksen ulkopuolelle. Käsityksen tutkimuksen yleispätevyydestä saa kuitenkin, kun ottaa huomioon, että lisäostokortteihin oikeutettuja perheitä syksyllä 1942 toimitetun elintarvikekorttijakelun ajankohtana Helsingin kansanhuoltolautakunnan silloin laatiman yhteenvedon mukaan oli kaikkiaan 628. Tästä määrästä vuonna 1943 tutkittujen tapausten luku, 575 , on 91,6 \%. Koska Helsingin väestösuhteet eivät puolen vuoden kuluessa ole paljonkaan muuttuneet, ei lomakkeiden palauttamisen laiminlyönnin johdosta selvityksen ulkopuolelle jääneiden perheiden määrän siis voitane katsoa sanottavasti heikentävän tutkimuksen tuloksia.

Sen sijaan tekee tutkittujen perheiden vähälukuisuus varovaisuuden tarpeelliseksi tehtäessä yleisiä johtopäätöksiä Helsingin väestöoloista tämän selvityksen perusteella. Käsittäähän aineisto vain puolen tuhatta yksityistapausta. Mutta tutkimuksenalaisten perheiden olot kyllä saavat tästä selvittelystä monenlaista valaisua.

Eräs huomautus on lisäksi tehtävä tutkimuksen tuloksiin nähden. Kohteensa puolesta selvitykseen nimittäin sisältyy se rajoitus, että se ei valaise kaikkien niiden helsinkiläisten perheiden oloja, joissa oli vähintään neljä lasta, vaan ainoastaan niiden, joissa ainakin neljä lasta oli määrättyä ikärajaa nuorempia sekä muun perheen yhteydessä eläviä. Näin ollen kysymykseen'tulivat vain »nuoret» perheet, s.o. sellaiset, joissa vanhemmat olivat niin nuoria, että neljä viimeistä lasta oli syntynyt 18 viimeisen vuoden kuluessa. "Vanhemmat» suuret perheet jäivät siten selvityksen ulkopuolelle. Tämä puutteellisuus johtui siitä, että tutkimus kyt- 
kettiin ostokorttien jakeluun. Mahdollisuuksia selvityksen toimeenpanoon muilla tavoin ei kuitenkaan ollut olemassa.

Tässä yhteydessä mainittakoon, että sellaisia ruokakuntia, joissa perheen kaikkien jäsenten luku oli vähintään kuusi, oli tilastollisen päätoimiston keväällä 1941 elintarvikekorttien jakelun yhteydessä suorittaman väestötiedustelun mukaan Helsingissä .yhteensä $2492^{1}$, mistä määrästä käsittelynalaiset 575 perhettä muodostavat vain $23,1 \%$.

Koska nyt esillä olevassa tutkimuksessa on kysymys sellaisista perheistä, jotka useassa tapauksessa vielä kasvavat, ei tässä yleensä ole tehty lasten erilaiseen lukumäärään perustuvia johtopäätöksiä, koska siten saatettaisiin johtua ennenaikaisiin tuloksiin. Sen sijaan on ryhmittelemällä tutkimuksenalaisia perheitä erilaisten perusteiden mukaan ja vertaamalla siten saatuja tietoja muhun Helsingin väestöoloja valaisevaąn tilastoaineistoon koetettu hankkia lisäselvitystä näistä pääkaupungin oloihin kảtsoen suurista perheistä ja niiden olosuhteista.

\section{PERHEIDEN SUURUUS JA KIELISUHTEET.}

Ryhdyttäessä tutkimuksen tuloksia selvittelemään lienee mielenkiintoista ensin luoda silmäys tutkimuksenalaisten perheiden suuruuteen. Mikäli tällöin otetaan huomioon perheiden kaikkien elossa olevien lasten lukumäärä, siis myös 18 vuotta vanhemmat lapset sekä otto- ja kasvattilapset, joita jälkimmäisiä kuitenkin oli vain 9 perheessä yhteensä 10 lasta, todetaan seuraavan yhdistelmän valossa Helsingin suurten ja keskisuurten sekä samalla »nuorten» perheiden määrä yllättävän pieneksi.

Kotikieli

Perheitä, joissa lapsia oli sinki 1944.

1 Helsingin kaupungin tilastollinen vuosikirja $34,1942-1943$, s. 35 . Hel- 
Kiinnitettäessä huomiota kielisuhteisiin havaitaan edellä olevasta asetelmasta, että suomenkielisiä perheitä oli 498 eli $86,6 \%$ ja ruotsinkielisiä 77 eli $13,4 \%$. Vertauksen vuoksi mainittakoon, että kaupungin koko läsnäolevasta väestöstä vúoden 1940 päättyessä suomenkielisiä oli $73,0 \%$, ruotsinkielisiä $25,4 \%$ ja muunkielisiä $1,6 \%$. Lasten lukumäärää tarkasteltaessa huomataan 9 - 12 lapsen perheiden olleen suhteellisesti yleisempiä ruotsinkuin suomenkielisten keskuudessa, mutta tutkittujen tapausten vähälukuisuus ei tässä oikeuta pitemmälle meneviin johtopäätöksiin.

Tutkimuksenalaisissa perheissä oli elossa olevia lapsia kaikkiaan 2928. Tällaisia suuria perheitä tämän käsitteen väestöpoliittisessa mielessä, esimerkiksi perheitä, joissa on ainakin 7 lasta, oli siis noin kolmannesmiljoonaa asukasta käsittävässä pääkaupungissa yllättävän vähän, vain 90 . Keskimääräinen lasten lukumäärä tutkimuksenalaisissa perheissä olikin ainoastaan 5,09 .

Sellaisia perheitä, joissa olisi ollut kaikkiaan 14 omaa lasta, ellei niissä lapsia olisi kuollut, oli 3 , sellaisia, joissa olisi ollut 13 lasta, 1, ja 12 lapsen perheitä 7. Kuolemantapauksia lasten keskuudessa oli sattunut yhteensä 171 perheessä $(29,7 \%$ kaikista perheistä). 15 perheessä $(2,6 \%$ kaikista perheistä) oli kuollut $3-6$ lasta, 38:ssa $(6,6 \%) 2$ lasta ja 118:ssa $(20,5 \%) 1$ lapsi. Mainittakoon, että erään ajomiehen perheeseen, jossa oli kuollut 3 lasta ja jossa vielä oli jäljellä 6 omaa lasta, oli otettu 2 kasvattilasta. 9 perheessä oli otto- tai kasvattilapsia. Niistä oli 3 perhettä sellaisia, joissa omia lapsia oli kuollut.

\section{AMMATTIRYHMITYS.}

Erityistä mielenkiintoa herättää kysymys suurten perheiden suhteellisesta määrästä eri yhteiskunta- ja ammattiryhmien keskuudessa. Tätä seikkaa valaisee osaltaan seuraava yhdistelmä, jossa perheet on ryhmitelty päähenkilön elinkeinohaaran ja ammattiaseman mukaan noudattaen samoja jaoitteluperusteita, joita on käytetty 27. 11. 1930 suoritetussa Helsingin väestölaskennassa. ${ }^{1}$

1 Suomen virallinen tilasto VI. Nide 71: 1, s. 48. Helsinki 1932. 
Elinkeinohaara
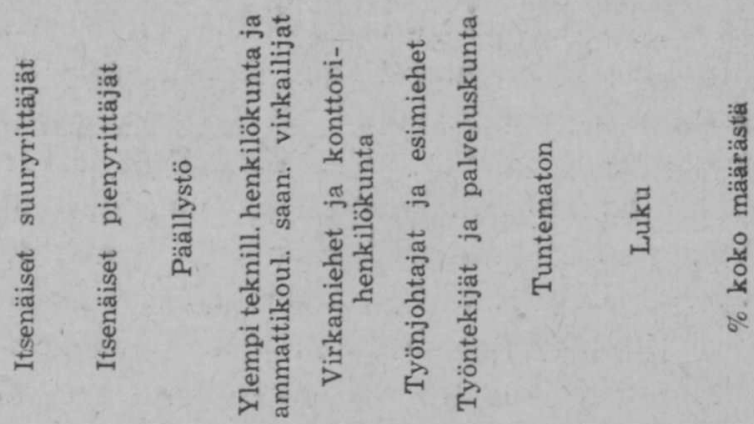

Maatalous sivuelin-

keinoineen

keinoineen $\ldots . .$. .

Teollisuus ja käsityö

Kauppa .......... 6

Julkinen toiminta .. -

Vapaat ammatit ... 11

Kotitaloustyö sekä

muut ammatit ...

Ilman ammattia tai

ammatti tuntematon

Yhteensä

$\begin{array}{llll}28 & 38 & 22 & 23\end{array}$

Yhteensä, $\%$......

$\begin{array}{lllllll}4,9 & 6,6 & 3,8 & 4,0 & 12,9 & 3,1 & 62,4\end{array}$

\begin{tabular}{rrrrrrrrr}
1 & - & - & - & - & 1 & - & 2 & 0,4 \\
23 & 8 & 11 & 7 & 8 & 192 & - & 257 & 44,7 \\
8 & - & 1 & 7 & 1 & 45 & - & 65 & 11,3 \\
4 & 10 & 2 & 9 & 4 & 10 & - & 45 & 7,8 \\
- & 1 & 5 & 47 & 5 & 63 & - & 121 & 21,0 \\
2 & 3 & 4 & 4 & - & 3 & - & 27 & 4,7 \\
- & - & - & - & - & 45 & - & 45 & 7,8 \\
& & & & & & & \multicolumn{4}{c}{} \\
- & - & - & - & - & - & 13 & 13 & 2,3 \\
38 & 22 & 23 & $\mathbf{7 4}$ & $\mathbf{1 8}$ & 359 & $\mathbf{1 3}$ & $\mathbf{5 7 5}$ & $\mathbf{1 0 0 , 0}$ \\
6,6 & 3,8 & 4,0 & 12,9 & 3,1 & 62,4 & 2,3 & 100,0 &
\end{tabular}

Suurin osa perheistä, lähes $2 / 3$, kuului siis työntekijäin ja palveluskunnan yhteiskunnalliseen ryhmään ja tästä erityisesti teollisuustyöväkeen (kokonaista 192 perhettä eli noin 1/3, nim. 33,4\%). Jotta kuitenkin voitaisiin vastata kysymykseen, missä ammattiryhmissä suuret perheet suhteellisesti katsoen olivat yleisimpiä myös näiden ryhmien suuruuden huomioonottaen, olisi tarpeen tietää, millä tavalla Helsingin kaikki perheet jakaantuivat eri ammattiryhmien kesken. Koska tällaista tilastoa ei kuitenkaan ole käytettävissä, verrattakoon tästä tutkimuksesta saatuja tuloksia seuraaviin lukuihin, jotka osoittavat, suuriko osa Helsingin perheiden päähenkilöistä ja yksityisistä itsenäisistä henkilöistä tilastollisen päätoimiston keväällä 1941 elintarvikekorttien jakelun yhteydessä 
suorittaman tiedustelun mukaan sekä vuonna 1930 toimeenpannun väestölaskennan mukaan kuului eri elinkeinohaaroihin.

\begin{tabular}{|c|c|c|c|}
\hline \multirow[t]{2}{*}{ Elinkeinohaara } & \multicolumn{2}{|c|}{$\begin{array}{c}\text { Helsingin kaikkien per- } \\
\text { heiden päähenkilöt ja } \\
\text { yksityiset itsenäiset, } \\
\%\end{array}$} & \multirow{2}{*}{$\begin{array}{c}\text { Tutkimuksenalaisten } \\
\text { perheiden pää- } \\
\text { henkilöt, } \\
\%\end{array}$} \\
\hline & v. 1941 & v. 1930 & \\
\hline Maatalous .......... & 0,5 & 1,5 & 0,4 \\
\hline Teollisuus ja käsityö ... & 32,1 & 30,0 & 44,7 \\
\hline Liikenne $. . . \ldots \ldots \ldots \ldots . . .$. & 6,1 & 6,7 & 11,3 \\
\hline Kauppa $\ldots \ldots \ldots \ldots \ldots \ldots$ & 18,5 & 19,7 & 7,8 \\
\hline Vapaat ammatit . & 17,7 & 7,4 & 21,0 \\
\hline Julkinen toiminta $\ldots \ldots \ldots \ldots$ & & 4,7 & 4,7 \\
\hline $\begin{array}{l}\text { Muut ammatit sekä ilman am- } \\
\text { mattia ja ammatti tuntematon }\end{array}$ & 25,1 & 30,0 & 10,1 \\
\hline Yhteensä $\quad \ldots \ldots \ldots \ldots \ldots \ldots$ & 100,0 & 100,0 & 100,0 \\
\hline
\end{tabular}

Edellä olevien numerojen mukaan on suuriperheisiä Helsingissä suhteellisesti eniten niiden ammattiryhmien keskuudessa, joihin kuuluvat saavat toimeentulonsa julkisista viroista tai toimista, teollisuudesta tai käsityöstä taikka sitten liikenteestä. Vähemmän suuria perheitä sen sijaan on kaupan alalla toimivien piirissä. Tämä seikka johtuu m.m. siitä, että kaupasta elatuksensa saavien joukossa on runsaasti naimattomia naisia, jotka tilastossa luetaan "yksityisten itsenäisten» ryhmään kuuluviksi. Koska edellä olevaan vertailevaan yhdistelmään sisältyy muitakin kuin perheiden päähenkilöitä, ei sen nojalla siis ole pääteltävissä, miten perheet jakaantuivat lukuisuutensa puolesta eri ammattiryhmien kesken, käytettävissä kun ei ole perheenmuodostuksen yleisyyttä eri ammattiryhmissä valaisevia tietoja.

Mielenkiintoista on myös verrata erilaisessa yhteiskunnallisessa asemassa, eri ammattiasemassa, olevia tutkimuksenalaisia perheitä vastaavassa asemassa olevien henkilöjen koko määrään. Koska uudempia lukuja ei ole käytettävissä, on tätä kysymystä selviteltäessä täytynyt tyytyä niihin tietoihin, jotka saatiin Helsingin väestölaskennassa vuonna 1930 . Seuraava yhdistelmä on saatu siten, että mainittua väestölaskentaa koskevasta tilastosta on laskettu, miten Helsingin väestö suhteellisesti jakaantui eri ammattiaseman 
omaaviin väestöryhmiin. ${ }^{1}$ Vertailun tulokset muodostuvat seuraavanlaisiksi:

\section{Ammattiasema}

Itsenäisiä elinkeinonharjoittajia

Päällystöä (johtajia ja isännöitsijöitä)

Ylempää teknillistä henkilökuntaa ja ammattikoulutuksen saaneita virkailijoita ... Virkamiehiä ja kontt.henkilöitä Työnjohtajia ja esimiehiä .... Työntekijöitä ja palveluskuntaa Yhteensä
Perheiden päähenkilöt Tutkimuksenalaisten ja yksityiset itsenäiset perheiden päähenkilöt,

$$
\text { v. } 1930 \text {, }
$$

10,4

$$
4,2
$$

21,6

2,0

60,7

100,0
13,2

11,7

100,0

Voidaan siis todeta, että Helsingin suurten perheiden suhteellinen määrä ei edellä olevien numerojen mukaan näytä olevan riippuvaisuussuhteessa ammattiasemaan, paitsi sikäli, että ne virkamiesten ja konttorihenkilökunnan keskuudessa ovat harvinaisempia kuin muissa yhteiskuntaryhmissä. Tämä johtuu suureksi osaksi naimattomien naisten lukuisuudesta konttorihenkilöjen keskuudessa.

\section{SIVISTYSTASO.}

\begin{tabular}{|c|c|c|}
\hline Sivistysmäärä & & \\
\hline Kansakoulukurssia suorittamattomia & $\begin{array}{l}\text { Luku } \\
48\end{array}$ & 8,4 \\
\hline Kansakoulun käyneitä ............. & 380 & 66,1 \\
\hline Keskikoulusivistyksen saaneita .... & 50 & 8,7 \\
\hline Ylioppilaita...$\ldots \ldots \ldots \ldots \ldots \ldots$ & 25 & 4,3 \\
\hline Korkeakoulututkinnon suorittaneita & 72 & 12,5 \\
\hline Yhteensä $\ldots \ldots \ldots \ldots \ldots \ldots \ldots \ldots$ & 575 & 100,0 \\
\hline
\end{tabular}

Tutkimuksenalaisten perheiden päähenkilöjen sivistystaso käy ilmi seuraavasta yhdistelmästä.

Suüten perheiden muodostuminen ei siis pääkaupungissa rajoitu ainoastaan siihen väestönosaan, joka ei ole saanut korkeampaa

1 Henkilöitä, jotka olivat ilman ammattia tai joiden ammatti oli tuntematon, ei tässä asetelmassa ole otettu huomioon. 
opillista sivistystä. Jonkinlaisen vertauskohdan saamiseksi rinnastetaan seuraavassa edellämainitut luvut Helsingin väestölaskennan yhteydessä vuonna 1930 saatuihin numeroihin, joista näkyy, suuriko osa Helsingin 30 vuotta täyttäneistä asukkaista kuului eri sivistysryhmiin.

Sivistysmäärä

30 v. täyttäneet asukkaat v. 1930

$$
\%
$$

Kansakoulukurssia suorittamattomia

Kansakoulun käyneitä ...........

Keskikoulukurssin suorittaneita ....

Korkeamman siv. saaneita .........

Sivistysmäärä tuntematon .........

Yhteensä

$\begin{array}{r}34,7 \\ 45,3 \\ 10,2 \\ 9,1 \\ 0,7 \\ \hline 000\end{array}$

100,0
Tutkimuksenalaisten perheiden päahenkilöt,

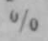

8,4

66,1

8,7

16,8

100,0

Sivistystaso, mikäli sitä voidaan mitata koulunkäynnin määrällä, oli näin ollen tutkimuksenalaisten perheiden päähenkilöjen keskuudessa korkeammalla kannalla kuin Helsingin 30 vuotta täyttäneen väestön keskuudessa yleensä.

Jo esitetyn lisäksi mainittakoon, että ammattikoulua oli tutkimuksenalaisten perheiden päähenkilöistä käynyt 70 eli 12,1 \%.

\section{ISOVANHEMPIEN KODIN LAPSILUKU.}

Kysymystä siitä, suuristako perheistä tutkimuksenalaisten perheiden vanhemmat itse olivat peräisin, valaisee seuraava yhdistelmä, joka osoittaa, montako lasta heidän vanhemmillaan aikoinaan oli ollut.

Perheitä, joiden äidin vanhemmilla

oli ollut lapsia

$1-3$
$4-6$
$7-9$
$10-12$
$13-15$
yli 15

Yhteensä
Perheitä, joiden isän vanhemmilla oli ollut lapsia

Yht.

$\begin{array}{rrrrrrr}1-3 & 4-6 & 7-9 & 10-12 & 13-15 & \text { yli } 15 & \\ 19 & 33 & 23 & 19 & 1 & - & 95 \\ 40 & 65 & 59 & 15 & 4 & 1 & 184 \\ 22 & 57 & 65 & 28 & 13 & 2 & 187 \\ 17 & 21 & 29 & 18 & 3 & 1 & 89 \\ 1 & 2 & 4 & 2 & 1 & - & 10 \\ 2 & 2 & 1 & 4 & 1 & - & 10 \\ 101 & 180 & \mathbf{1 8 1} & \mathbf{8 6} & \mathbf{2 3} & \mathbf{4} & \mathbf{5 7 5}\end{array}$


Siis sellaisia perheitä, joiden molemmilla isovanhemmilla on ollut ainakin 4 lasta, oli 398 eli yli kaksi kolmannesta tutkituista perheistä, nim. $69,2 \%$. Sellaisia perheitä, joiden toisella isovanhemmalla on ollut vähintään 4 lasta, olivat miltei kaikki (556) eli $96,7 \%$, sellaisia, joiden suhteen mainittu minimiluku oli 7,418 eli $72,7 \%$ ja sellaisiakin, joiden toisella isovanhemmalla on ollut ainakin 10 lasta, niin suuri määrä kuin 192 eli $32,7 \%$ tutkituista perheistä.

\section{NYKYISTÄ AVIOLIITTOA EDELTÄNEET LAPSET.}

Sellaisia perheitä, joissa äidillä oli lapsia hänen edellisestä avioliitostaan, oli $23(4,0 \%)$ sekä sellaisia, joissa isällä oli edellisessä avioliitossa syntyneitä lapsia, $30(5,2 \%)$. Sellaisia perheitä taas, joissa oli ennen avioliiton solmimista syntyneitä yhteisiä lapsia, oli $59(10,3 \%)$ ja sellaisia, joissa äidillä oli aviottomia lapsia ajalta ennen avioliiton solmimista, $9(1,6 \%)$.

\section{VANHEMPIEN NAIMISIINMENOIKÄ.}

Kysymystä siitä, minkä ikäisinä tutkimuksenalaisten perheiden vanhemmat ovat solmineet avioliiton, valaisee seuraava yhdistelmä.

Äidin ikä avioliittoa solmittaes-

sa, $v$.

Alle 20

20-21

$22-23$

$24-25$

$26-27$

28-29

$30-31$

$32-33$

$34-35$

$36-37$

38- 39

Yli 40

Yhteensä
Isän ikä avioliittoa solmittaessa, v.

Alle 20-22-24-26-28-30-32-34-36-38- Yli Yht. $\begin{array}{llllllllllll}20 & 21 & 23 & 25 & 27 & 29 & 31 & 33 & 35 & 37 & 39 & 40\end{array}$

$\begin{array}{lllllllllllll}6 & 14 & 12 & 7 & 4 & 2 & 5 & 3 & - & 1 & - & 1 & 55\end{array}$

$\begin{array}{lllllllllllll}4 & 15 & 21 & 31 & 16 & 7 & - & 4 & - & 2 & 1 & 2 & 103\end{array}$

$\begin{array}{lllllllllllll}5 & 6 & 23 & 28 & 25 & 15 & 11 & 5 & 1 & -- & 1 & 2 & 122\end{array}$

$\begin{array}{lllllllllllll}2 & 9 & 17 & 27 & 23 & 20 & 6 & 8 & 3 & 2 & 2 & - & 119\end{array}$

$\begin{array}{rrrrrrrrrrrr}- & 2 & 5 & 10 & 13 & 12 & 9 & 8 & 2 & 3 & - & 5\end{array}$

- 127

$-\quad-1$

$---$

$1-\begin{array}{lllll}1 & 1 & 1 & 1\end{array}$

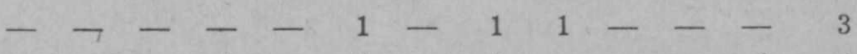

$---1-1-1-14$

$\begin{array}{llllllllllllll}18 & 47 & 80 & 113 & 95 & 72 & \overline{46} & \overline{41} & \overline{14} & \overline{14} & 7 & 28 & 575\end{array}$ 
Tästä tilastosta ilmenee, että yleisin naimisiinmenoikä perheiden isien keskuudessa on ollut $24-25 \mathrm{v}$. ja äitien joukossa $22-23$ v. Koko maassa samoinkuin Helsingissäkin vastaavat luvut ovat olleet miesten keskuudessa $25-29$ v. ja naisten $20-24$ v. Mitään erikoisuutta ei siis tässä suhteessa voida havaita tutkimuksenalaisissa perheissä.

\section{HELSINGISSA SYNTYNEET JA MUUALTA MUUTTA- NEET VANHEMMAT.}

Kuten on tunnettua, perustuu suurten ja keskikokoistenkin kaupunkien väestöjen kasvu siihen, että maaseudulta jatkuvasti suuntautuu kaupunkeihin työkykyisessä iässä olevien ihmisjoukkojen virta. Ellei tällaista ilmiötä tapahtuisi, s.o. jos kaupunkien olisi pakko väestönsä suhteen olla omavaraisia, ne ajan mittaan kuolisivat sukupuuttoon. Tämän osoittaa Helsingin suhteen se tosiasia, että pääkaupunkimme väestön nettouusiutumisluvun v. 1931 on laskettu olleen 0,381 , s.o. jos muuttoliike ja Helsingin väestön poikkeavaisuus normaalista ikärakenteesta otaksutaan olemattomaksi, oli Helsingin väestön hedelmällisyys vain $38,1 \%$ siitä, mitä sen pitäisi olla, jotta väestö jatkuvasti pysyisi entisen suuruisena. ${ }^{1}$

Maaseudulta tulevan ihmisaineksen perustava merkitys perheenmuodostukselle ja väestön kasvulle kuvastuu myös seuraavasta yhdistelmästä, joka osoittaa muualta maasta muuttaneiden osuuden tutkimuksenalaisten perheiden muodostumisessa. Asetelmassa perheet on ryhmitelty vanhempien Helsinkiin muuttoiän mukaan.

Kuinka vanhana perheenisä on muuttanut Helsinkiin

Kuinka vaǹhana perheenäiti on muuttanut Helsinkiin

Syntyp. helsink.
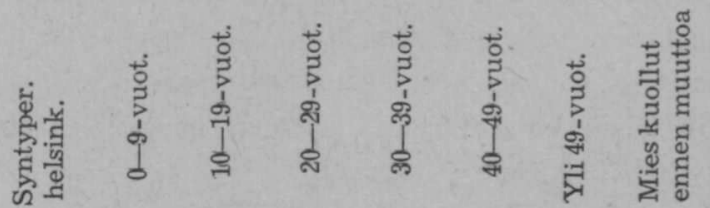

$0-9$-vuot.

$\begin{array}{rrrr}31 & 9 & 14 & 14 \\ 8 & 4 & 6 & 8 \\ 15 & 6 & 21 & 43\end{array}$

$\begin{array}{lccc}5 & 2 & - & - \\ 3 & - & - & - \\ 6 & - & 1 & -\end{array}$

10-19-vuot.

Kannisto, Helsingin väestötase. Suomalainen Suomi n:o 2 v. 1941. 
20-29-vuot.

30-39-vuot.

$40-49$-vuot.

Yli 49-vuot.

Yhteensä $\begin{array}{rrrrr}29 & 7 & 21 & 105 & 55 \\ 2 & - & 3 & 6 & 84 \\ - & - & - & 1 & 8 \\ - & - & - & - & -\end{array}$

$\begin{array}{llllll}85 & 26 & 65 & 177 & 161 & 54\end{array}$

4
25
23

$$
\begin{array}{r}
1 \\
3 \\
-
\end{array}
$$

Asetelmasta näkyy, että sellaisia perheitä, joissa kumpikin vanhemmista oli syntyperäinen helsinkiläinen, oli vain 31 eli $5,4 \%$ sekä sellaisiakin, joissa vain toinen vanhemmista oli syntyperäinen helsinkiläinen, ainoastaan 98 eli 17,0 \% . Sen sijaan sellaisia perheitä, joissa kumpikin vanhemmista oli muualta muuttaneita, oli 446 eli $77,6 \%$. Yleisin muuttoikä on sekä miesten että naisten ryhmässä ollut $20-29$ vuotta eli siis juuri se ikäkausi, jolloin tavallisesti oma koti perustetaan.

\section{TULO- JA VARALLISUUSSUHTEET.}

Tutkimuksenalaisten perheiden jakaantuminen kuukausitulojen mukaan käy selville seuraavasta yhdistelmästä.

$\mathrm{Kuukausitulot,} \mathrm{mk}$

Perheitä,

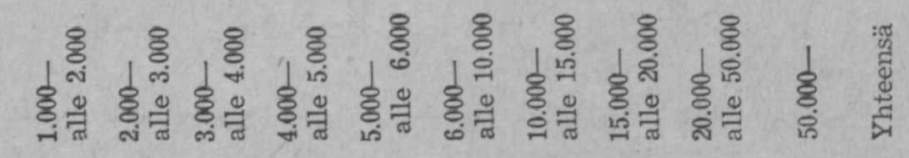

$$
\begin{array}{llllllllllll}
\text { luku } & 39 & 112 & 139 & 110 & 55 & 58 & 34 & 11 & 10 & 7 & 575
\end{array}
$$

Perheitä,

$$
\begin{array}{llllllllllll}
\% & 6,8 & 19,5 & 24,2 & 19,1 & 9,6 & 10,1 & 5,9 & 1,9 & 1,7 & 1,2 & 100,0
\end{array}
$$

Tämän asetelman suurimmasta tuloryhmästä mainittakoon, että suurituloisimman perheen kuukausitulot olivat Helsingin verotuskalenterin mukaan 104.700 markkaa ja lähinnä suurituloisimman 50.700 markkaa kuukaudessa.

Millaisia käsiteltävänä olevien perheiden tulot olivat verrattuina helsinkiläisten tuloihin yleensä, käy ilmi tarkasteltaessa Helsingin kunnallisverotilastoa. Tämä osoittaa, että verotetuista kaupunkilaisista oli $75,4 \%$ eli siis yli $3 / 4$ sellaisia, joilla v. 1941 oli alle 30.000 markan vuositulot. Sen sijaan lähes $9 / 10: 1 l a(88,2 \%)$ tutkimuksenalaisista perheistä oli yli 30.000 markan tulot vuo- 
dessa. Nämä luvut viittaavat - vaikka otetaankin huomioon verotukseen ilmoitettujen tulojen todellista pienempi määrä — siihen, että suurimmalla osalla pääkaupungin väestöstä ei näytä olevan taloudellisia mahdollisuuksia huolehtia useasta lapsesta. Tutkimuksenalaisista perheistä taas suurin osa eli niukoissa tai ainakin vaatimattomissa oloissa, sillä nuistä oli $69,7 \%$ :lla alle 60.000 markan vuositulot. Mutta on kuitenkin todettava, että suuria perheitä oli jonkin verran korkeammissakin tuloluokissa. Nämä tulokset näyttävät joka tapauksessa korostavan pääkaupungissa vallitsevan lapsiköyhyyden taloudellisten syiden merkitsevyyttä.

Kokonaista 137 perhettä $(23.8 \%)$ oli sellaisia, että niille oli pantu maksettavaksi veroa omaisuudesta. Vastaava luku Helsingin kaupungissa oli vuonna 19388.979 fyysillistä henkilöä eli vain $3,6 \%$ kaupungin koko hengillekirjoitetusta väestöstä. Tämä seikka on sopusoinnussa edellämainitun vähätuloisten pääkaupunkilaisten suuren määrän kanssa.

Perheiden toimeentulon kannalta mielenkiintoista kysymystä äidin ja lasten ansiotyön yleisyydestä tutkimuksenalaisissa perheissä valaisee seuraava taulukko.

\begin{tabular}{|c|c|c|c|c|c|c|c|c|c|}
\hline \multirow{3}{*}{ 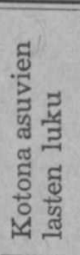 } & \multirow[b]{3}{*}{ 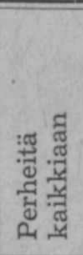 } & \multicolumn{8}{|c|}{ Perheitä, joissa } \\
\hline & & \multicolumn{2}{|c|}{ isä ansaitsee } & \multicolumn{2}{|c|}{ äiti ansaitsee } & \multicolumn{2}{|c|}{ laps. ansaitsevat } & \multicolumn{2}{|c|}{$\begin{array}{c}\text { on "muita» } \\
\text { tuloja }\end{array}$} \\
\hline & & 茎 & 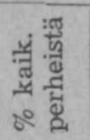 & 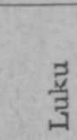 & 불 & $\frac{\vec{y}}{3}$ & 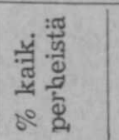 & 壱 & 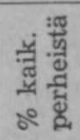 \\
\hline 1 & 2 & 2 & 100 & 1 & 50,0 & - & - & - & - \\
\hline 2 & 4 & 4 & 100 & 1 & 25,0 & - & - & - & - \\
\hline 3 & 15 & 14 & 93,3 & 1 & 16,7 & 3 & 20,0 & - & - \\
\hline 4 & 311 & 270 & 86,8 & 74 & 23,8 & 64 & 20,6 & 28 & 9,0 \\
\hline 5 & 128 & 117 & 91,4 & 17 & 13,3 & 47 & 36,7 & 13 & 10,2 \\
\hline 6 & 61 & 55 & 90,0 & 16 & 26,2 & 34 & 55,7 & 2 & 3,3 \\
\hline 7 & 30 & 28 & 93,3 & 3 & 10,0 & 21 & 70,0 & 2 & 6,6 \\
\hline 8 & 15 & 14 & 93,3 & - & - & 11 & 73,3 & 2 & 13,3 \\
\hline 9 & 5 & 5 & 100 & - & - & 5 & 100 & 1 & 20,0 \\
\hline 10 & 4 & 4 & 100 & - & - & 3 & 75,0 & - & - \\
\hline $\begin{array}{l}\text { Kaik- } \\
\text { kiaan }\end{array}$ & 575 & 513 & 89,2 & 113 & 19,7 & 188 & 32,7 & 48 & 8,3 \\
\hline
\end{tabular}


Perheiden keskuudessa oli siis äitien ansiotyöllä $(19,7 \%)$ huomattava merkitys. Numerot osoittavat, että - niinkuin on luonnollistakin - perheenäitien ansiotyön yleisyys vähenee, sitä mukaa kuin perheet suurenevat. Suuremmissa perheissä sensijaan lasten ansiotyö on merkittävämpää.

Miten perheet, joissa äiti kävi ansiotyössä, jakaantuivat päähenkilön ammatin ja ammattiaseman mukaan, näkyy seuraavista yhdistelmistä.

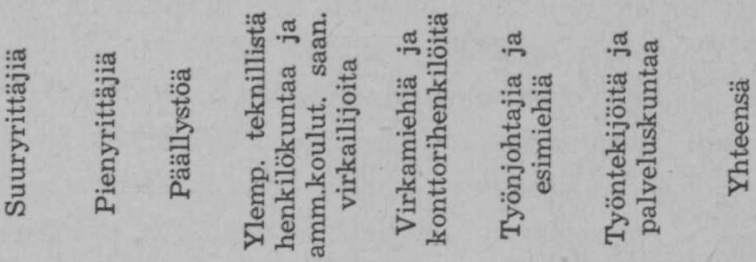

Perheitä, joissa äiti

ansaitsee, luku

Perheitä, joissa äiti

ansaitsee, $\%$

Tutkimuksenalai-

sia perheitä

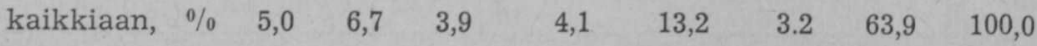

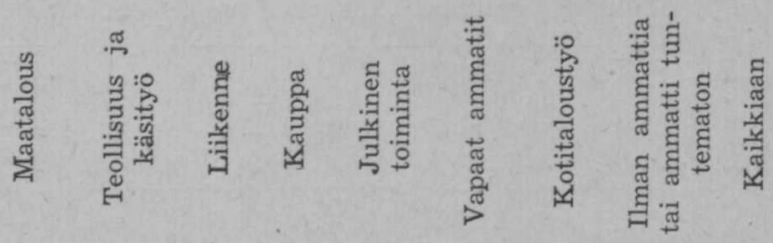

Perheitä, joissa äiti

$\begin{array}{llllllllll}\text { ansaitsee, luku } & - & 30 & 8 & 23 & 27 & 1 & 17 & 7 & 113\end{array}$

Perheitä, joissa äiti

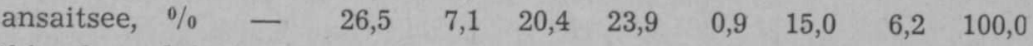

Tutkimuksenalai-

sia perheitä ,

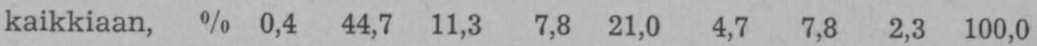

1 Henkilöt, jotka olivat ilman ammattia tai joiden ammatti oli tuntematon, eivät sisälly tähän asetelmaan. 
Näiden kahden asetelman luvut osoittavat, että perheenäitien ansiotyö tutkimuksenalaisten perheiden keskuudessa oli suhteellisesti yleisintä virkamiesten ja konttorihenkilöiden ryhmään kuuluvissa perheissä sekä, mikäli kiinnitetään huomio ammattiin, perheissä, joissa päähenkilöt toimivat kaupan tai kotitaloustyön alalla. Viimeksimainittuun ryhmään kuuluvissa perheissä päähenkilönä oli vaimo.

Perheitä, joissa isä oli kuollut, sisältyi tutkimukseen kaikkiaan 42 eli $7,3 \%$. Nämä jakaantuivat tuloryhmittäin seuraavasti:

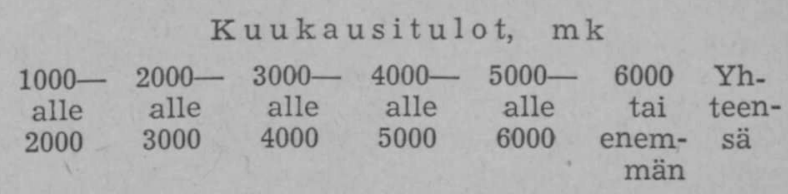

Perheitä, joissa isä

on kuollut, luku

12

16

8

4

2

- 42

Perheitä, joissa isä

on kuollut, $\%$

28,6

38,1

19,0

9,5

4,8

$-\quad 100,0$

Perheitä kaik-

kiaan, $\%$

$19,5 \quad 24,2$

19,1

$9,6 \quad 20,8 \quad 100,0$

Nämä luvut osoittavat, miten isää vailla olevat perheet elivät taloudellisesti keskimääräistä paljon niukemmissa olosuhteissa. Isän kuoleman ohella toinen huomattava - ajankohtainen - syy perheenäidin työssäkäynnin välttämättömyyteen saattoi olla perheen päämiehen sotapalveluksessa olo. Palvelukseen kutsutuille kuuluvilla taloudellisilla eduillahan yksinomaan oli pääkaupungissa vaikeata tulla toimeen. Tällaisia perheitä oli kaikkiaan 108 (18,8 $\%$ ). Niistä valtaosa (64 eli $59,3 \%$ ) kuului ryhmään, jonka kuukausitulot olivat alle 4.000 markkaa. 16:1la oli vain alle 2.000 markan kuukausitulot ja lisäksi 17 :llä perheellä alle 3.000 markan tulot kuukaudessa.

\section{ASUNTO-OLOT.}

Suuri osa tutkimuksessa hankituista tiedoista koski nykyään niin ajankohtaista asuntokysymystä. M.m. selviteltiin asunnon hallintamuodot tutkimuksenalaisten perheiden keskuudessa. Ne 
ilmenevät seuraavasta yhdistelmästä, josta myös näkyvät asuntojen suuruussuhteet. Huoneiden lukumäärään nähden on huomattava, että keittiö on katsottu huoneeksi, mutta ei keittokomeroa.

\begin{tabular}{|c|c|c|c|c|c|}
\hline \multirow{2}{*}{$\begin{array}{l}\text { Asunnon huo- } \\
\text { neiden luku }\end{array}$} & \multicolumn{3}{|c|}{ Perheitä, joilla oli } & \multicolumn{2}{|c|}{ Yhteensä } \\
\hline & $\begin{array}{c}\text { oma } \\
\text { asunto }\end{array}$ & $\begin{array}{c}\text { oma asun- } \\
\text { to-osake }\end{array}$ & $\begin{array}{l}\text { vuokra- } \\
\text { asunto }\end{array}$ & Luku & $\%$ \\
\hline 1 & - & 1 & 141 & 142 & 24,7 \\
\hline 2 & - & 8 & 242 & 250 & 43,5 \\
\hline 3 & 7 & 10 & 68 & 85 & 14,7 \\
\hline 4 & 2 & 6 & 27 & 35 & 6,1 \\
\hline 5 & - & 4 & 23 & 27 & 4,7 \\
\hline 6 & 1 & 9 & 17 & 27 & 4,7 \\
\hline 7 & - & 2 & 5 & 7 & 1,2 \\
\hline 8 & - & - & 2 & 2 & 0,4 \\
\hline Yhteensä & 10 & 40 & 525 & 575 & 100,0 \\
\hline
\end{tabular}

Jotta saataisiin käsitys edellämainittujen numerojen merkityksestä, verrattakoon niitä sosiaaliministeriön sosiaalisen tutkimustoimiston julkaisemaan erikoistutkimukseen kaupunkien asuntoosoista vuonna $1938^{1}$ sisältyviin Helsinkiä koskeviin tietoihin. Asuntojen suuruuden osalta vertailu muodostuu seuraavanlaiseksi:

Asuntoja (\%:eina), joiden Huoneita huoneluku oli asuntoa Kaikki Helsingin asunnot ..... $\quad \begin{array}{llllll}1 & 2 & 3 & 4 & 5 & \text { Yht. kohden }\end{array}$ Tutkimuksenalaisten perheiden

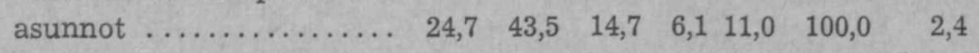

Nämä luvut osoittavat, että käsiteltävänä olevilla perheillä ei näiden suhteellisesta suuruudesta huolimatta juuri ollut absoluuttisestikaan sen tilavampia asuntoja kuin helsinkiläisillä yleensä. Se, että osaa jälkimmäisten yhden huoneen huoneistoista edellisillä vastasivat kaksi huonetta käsittävät asunnot, on täysin luonnollista. Tutkimuksenalaisten perheiden suurimman osan asunnot olivat siis vielä keskimääräistäkin ahtaammat.

Sosiaalisen tutkimustoimiston mainittu asuntotutkimus kohdistui pääosaltaan pienasuntoihin (enintään 3 huonetta). Näitä

1 Kaupunkien asunto-olot vuonna 1938. Suomen virallinen tilasto XXXII. Sosiaalisia erikoistutkimuksia 19 . Helsinki 1940. 
koskeva selvityksen osa suoritettiin edustavasti, siinä kun tarkastelun kohteeksi Helsingissä otettiin joka 7:s pienasunnoista. Tällaisista oli omistajan hallussa $1,1 \%$ (nyt käsiteltävänä olevien perheiden keskuudessa oli vastaava luku, kuten edellisellä sivulla olevasta yhdistelmästä näkyy, 10 eli 1,7\%), asunto-osakkeenomistajilla $16,6 \%$ (vastaava luku tutkimuksenalaisissa perheissä oli 7,0\%) ja vuokranottajien hallussa $82,3 \%$ (vastaava luku tässä tutkimuksessa oli $91,3 \%$ ). Tutkimuksenalaisten perheiden keskuudessa àsunto-osakkeiden omistajia siis oli suhteellisen vähän vuokralla asumisen ollessa miltei yksin vallitsevaa. Nyt käsiteltävänä olevien perheiden hallussa olevista täysin omista asunnoista oli pienimmässä kaksi huonetta ja keittiö.

Asunnoista oli 265 eli 46,1 \% (vastaava luku Helsingin pienasunnoissa oli $57,2 \%$ ) sellaisia, joissa oli keskuslämmitys, ja 310 eli $53,9 \%$ (pienasunnoissa $42,8 \%$ ) sellaisia, joissa oli uunilämmitys. Jälkimmäinen lämmitystapa näyttää siis tutkimuksenalaisten perheiden asunnoissa olleen tavallista yleisempää.

Seuraava yhdistelmä osoittaa erikokoisten huoneistojen jakaantumisen perheen suuruuden mukaan.

Asunnon

huoneiden

luku alle

$\begin{array}{ccrrrrrrrrr} & 5 & 5 & 6 & 7 & 8 & 9 & 10 & 11 & 12 & \\ 1 & 6 & 20 & 66 & 25 & 15 & 9 & 1 & - & - & 142 \\ 2 & 1 & 20 & 111 & 63 & 24 & 13 & 11 & 5 & 2 & 250 \\ 3 & - & 6 & 39 & 19 & 12 & 8 & 1 & - & - & 85 \\ 4 & - & 2 & 24 & 5 & 1 & 1 & 1 & 1 & - & 35 \\ 5 & - & 1 & 21 & 5 & - & - & - & - & - & 27 \\ 6 & - & - & 21 & 5 & 1 & - & - & - & - & 27 \\ 7 & - & 1 & 4 & 1 & - & - & - & 1 & - & 7 \\ 8 & - & - & 2 & - & - & - & - & - & - & 2 \\ \text { Yhteensä } & \mathbf{7} & \mathbf{5 0} & \mathbf{2 8 8} & \mathbf{1 2 3} & \mathbf{5 3} & \mathbf{3 1} & \mathbf{1 4} & \mathbf{7} & \mathbf{2} & \mathbf{5 7 5} \\ \text { Yht., \% } & 1,2 & \mathbf{8 , 7} & 50,1 & 21,4 & 9,2 & 5,4 & 2,4 & 1,2 & 0,4 & 100,0\end{array}$

Tätä asetelmaa silmäiltäessä kiinnittää huomiota, että suurten perheiden asunnot eivät olleet absoluuttisestikaan väljempiä kuin pienempien perheiden. Tämä huomio vahvistaa edellä mainittua toteamusta käsittelynalaisten perheiden asuntojen ahtaudesta. 
Seuraava yhdistelmä osoittaa, montako muuta henkilöä perheenjäsenten lisäksi asui perheiden yhteisissä asunnoissa.

\begin{tabular}{cccccc}
$\begin{array}{c}\text { Asunnon } \\
\text { huoneiden } \\
\text { luku }\end{array}$ & \multicolumn{2}{c}{$\begin{array}{c}\text { Perheitä, joissa asui perheenjäsenten } \\
\text { lisäksi }\end{array}$} & $\begin{array}{c}\text { Yhteensä } \\
\text { muita omaisia }\end{array}$ & $\begin{array}{c}\text { Perheitä } \\
\text { kaiapulaisia } \\
\text { kaik- } \\
\text { kiaan }\end{array}$ \\
$\begin{array}{ccccc}\text { asukkeja } \\
2\end{array}$ & 13 & - & - & 13 & 142 \\
3 & 18 & 6 & 8 & 32 & 250 \\
4 & 7 & 7 & 6 & 20 & 85 \\
5 & 2 & 18 & 3 & 23 & 35 \\
6 & 2 & 19 & 1 & 22 & 27 \\
7 & 4 & 22 & - & 26 & 27 \\
8 & - & 7 & - & 7 & 7 \\
Yhteensä & - & 2 & - & 2 & 2 \\
Yhteensä, $\%$ & $\mathbf{4 6}$ & $\mathbf{8 1}$ & $\mathbf{1 8}$ & $\mathbf{1 4 5}$ & $\mathbf{5 7 5}$ \\
kaik. perheistä & 8,0 & 14,1 & 3,1 & 25,2 & 100,0
\end{tabular}

Kuten luonnollista onkin, oli kotiapulaisia suhteellisesti eniten suurissa huoneistoissa. Muihin omaisiin ja asukkeihin nähden asianlaita sen sijaan oli päinvastainen. Vuoden 1941 väestötiedustelun mukaan oli Helsingin ruokakunnista $6,6 \%$ sellaisia, joissa oli kotiapulaisia, sekä 8,4\% sellaisia, joiden luona majaili asukkeja. Kaikkiaan yli 1/4 käsittelynalaisista perheistä oli - sellaisia, että niissä perheenjäsenten lisäksi asui muitakin omaisia. Palkattua aputyövoimaa (kotiapulaisia, päiväapulaisia y.m.) käytettiin 85 $(14,8 \%)$ perheessä. Nämä olivat valtaosaltaan (64 perhettä) sellaisia, joissa oli neljä kotona asuvaa lasta.

Perheen koko tuloista laskettu vuokraprosentti oli eri tuloluokissa keskimäärin 16,0. Vastaava pienasuntotutkimuksessa saatu luku oli ennen viimeisiä sotia, vuonna $1938,22,4 \%$.

Selvityksen yhteydessä koottiin tietoja myöskin siitä, kuinka suuressa määrässä tutkimuksenalaisten perheiden keskuudessa suoritettiin omakohtaista palstaviljelystoimintaa. Tulokseksi saatiin, että niin huomattava määrä kuin 291 perhettä $(50,6 \%)$ harjoitti kasvitarhaviljelystä. Suurimmalla osalla perheistä oli tällöin käy. tettävissään ainoastaan vuokramaata (270 perhettä eli $47,0 \%$ ) vain 21 perheen $(3,7 \%)$ saattaessa omalla maallaan viljelystä ylläpitää. 


\section{PERHEET KAUPUNGINOSIEN MUKAAN.}

Millä tavalla tutkimuksenalaiset perheet suhteellisesti jakaantuivat Helsingin eri osien kesken, käy ilmi seuraavasta yhdistelmästä. Asukasmäärät siinä tarkoittavat hengillekirjoitettua väestöä vuoden 1942 alussa. Ruokakuntien luku taas on saatu edellä monesti mainitusta elintarvikekorttien jakelun yhteydessä keväällä 1941 suoritetusta väestötiedustelusta.

\begin{tabular}{|c|c|c|c|c|c|c|c|}
\hline \multirow{2}{*}{\multicolumn{2}{|c|}{$\begin{array}{l}\text { Alue (suluissa kaup.osien } \\
\text { numero) }\end{array}$}} & \multicolumn{2}{|c|}{$\begin{array}{l}\text { Tutkimuksen- } \\
\text { alaisia perheitä }\end{array}$} & \multicolumn{2}{|c|}{$\begin{array}{l}\text { Asukkaita } \\
\text { kaikkiaan }\end{array}$} & \multicolumn{2}{|c|}{$\begin{array}{l}\text { Ruoka- } \\
\text { kuntia }\end{array}$} \\
\hline & & Luku & $\%$ & Luku & $\%$ & Luku & $\%$ \\
\hline 1 & Kruununhaka (I) & 30 & 5,2 & 14.209 & 5,6 & 6.206 & 5,6 \\
\hline 2 & Keskusta (II, III ja IV) & 46 & 8,0 & 28.896 & 11,4 & 13.441 & 12,2 \\
\hline 3 & Punavuori ja Eira (V ja VI) & 31 & 5,4 & 21.746 & 8,6 & 10.940 & 10,0 \\
\hline 4 & Kaivopuisto (VII ja IX) .... & 32 & 5,6 & 20.9 & 8,2 & 9.050 & 8,2 \\
\hline & Katajanokka (VIII) ..... & & & & 1,8 & & 1,6 \\
\hline & Söörnäinen (X-XII) & 163 & 28 & & 26,4 & 590 & 28,7 \\
\hline & Töölö (XIII-XV) … & 77 & 13 & 56.492 & 22,2 & 3.476 & 21,4 \\
\hline & zan alue ja Ruskeasuo (XVI) & 2 & 0 , & 703 & 0,3 & 262 & 0,2 \\
\hline & Pasila $\ldots \ldots \ldots \ldots \ldots \ldots \ldots$ & 8 & 1,4 & 1.754 & 0,7 & 890 & 0,8 \\
\hline & Vallila, Hermanni, Kumpula ja & & & & & & \\
\hline & Toukola (m.m. XXI-X) & & & 22.251 & 8 & 7.749 & 7,1 \\
\hline & Käpylä $(X X V-X X V I) \ldots \ldots$. & & & 8.212 & & 2.370 & 2,2 \\
\hline & Jätkäsaari ja Lapinlahti (XX) & - & & 271 & 0,1 & 65 & 0,1 \\
\hline & $\begin{array}{l}\text { Suomenlinna ja muut saaret } \\
\text { sekä muut henkilöt } \ldots \ldots \ldots \ldots\end{array}$ & 2 & & & & 493 & 0,4 \\
\hline & Muut alueet rautatien länsip. & 14 & 2,4 & 2.258 & 0 , & 583 & 0,5 \\
\hline & it alueet rautatien itäpuol. & -1 & 一 & 472 & 0,2 & 1.147 & 1,0 \\
\hline & & 575 & 100,0 & 253.890 & 100,0 & 109.999 & 100,0 \\
\hline
\end{tabular}

Suuria perheitä oli siis keskimääräistä enemmän etenkin Vallilassa, Hermannissa, Kumpulassa ja Toukolassa ja taas huomattavasti keskimääräistä vähemmän Töölössä. Eräänä syynä tämän kaupunginosan viimeiseen järjestyssijaan on, että se Helsingin kaupungin alueista on naisrikkain, joten siellä tästä syystä on paljon naimattomia naisia. 


\section{PERHEIDEN VÄESTÖPOLIITTISIA TOIVOMUKSIA.}

Kyselylomakkeessa oli varattu myöskin tilaa, jossa vanhemmat saivat esittää ajatuksensa siitä, miten suurten perheiden asemaa olisi helpotettava. Tällaisia toivomuksia esitettiinkin 507 vastauksessa. Ensi sijalla näissä mielipiteen ilmaisuissa oli kylläkin erittäin ajankohtainen toivomus asunto-olojen parantamisesta, minkä toi julki 141 lomakkeen palauttajaa. Verohelpotuksia odotti $112^{1}$, suurempia säännöstelynalaisten elintarvikkeiden jakelumääriä 80 , lapsi- ja raha-avustuksia sekä perhelisiä 58 , omakotilainoja 34 , parannusta kotiapulaiskysymykseen 21 , helpotusta oppikoulumaksuihin 17 , parempia palkkoja 14, jonotuskortteja perheenäideille 8 , omaa viljelyspalstaa 7 , perheenäideille kesälomia 5 , työtyttöjen järjestämistä suurten perheiden avuksi 5 , kodinperustamislainoja 2 , palkintoja suuriperheisille 2 sekä äitiys- ja lastenhuollon uskomista kansaneläkelaitokselle 1 .

1 Vuonna 1943, tutkimuksen toimittamisen jälkeen, tulo- ja omaisuusverotuksen uudistus saatiinkin toteutetuksi, ja myöskin kunnallisverotuksen lapsivähennyksiä korotettiin. Täten suuriperheisten verotaakkaa huomattavasti kevennettiin. 